\title{
Printed and e-book: problems of choice of modern students of the university
}

\section{Livro impresso e digital: o problema de escolher dos estudantes da universidade moderna}

\section{Libro impreso y digital: el problema de elegir en estudiantes universitarios modernos}

\author{
Olena Budnyk ${ }^{1}$ (D), Tetiana Kachak ${ }^{1}$ iD), Tetyana Blyznyuk ${ }^{1}$ iD, \\ Nadiia Rostykus ${ }^{2}$ iD, Halyna Boiko ${ }^{2}$ iD \\ ${ }^{1}$ Vasyl Stefanyk Precarpathian National University, Ivano-Frankivsk, Ukraine. \\ 2 Ivan Franko National University of Lviv, Lviv, Ukraine. \\ Corresponding author: \\ Olena Budnyk \\ Email: olena.budnyk@gmail.com
}

How to cite: Budnyk, O., Kachak, T., Blyznyuk, T., Rostykus, N., \& Boiko, H. (2021). Printed and e-book: problems of choice of modern students of the university. Revista Tempos e Espaços em Educação, 14(33), e15913.

http://dx.doi.org/10.20952/revtee.v14i33.15913

\begin{abstract}
The article highlights the urgency of the problem of digitalization of education, substantiates the need to develop digital competence of young people in the context of using various electronic resources, technologies, the ability to be critical of the accuracy of information, competently use digital media to achieve personal, professional or social goals. The need for the development of reading competence in university students is emphasized. The study used methods of conceptual and comparative analysis, as well as psychodiagnostic and statistical methods. The results of an empirical study conducted in Ukrainian universities on the researched problem are presented. The positive and negative sides in the use of printed and electronic publications by modern students are given. Their preferences for using these sources to solve educational problems are revealed. The peculiarities of the development of readers' interests of future specialists and the prospects of competition of the printed book with the electronic one are determined. According to the survey, it was found that respondents prefer e-books, they have more advantages in terms of practical application. It is investigated that for study they more often choose printed books, textbooks, which help them to focus more deeply on scientific information and to comprehend it critically (more than $70 \%$ of respondents). Emphasis on the importance in modern conditions of a successful combination in educational (professional) activities of electronic and printed publications.
\end{abstract}

Keywords: Digitization of education. E-book. Educational process. Printed book. Reading culture. 


\section{RESUMO}

O artigo destaca a urgência do problema da digitalização da educação, fundamenta a necessidade de desenvolver a competência digital dos jovens no contexto do uso de recursos eletrônicos diversos, tecnologias, a capacidade de ser crítico em termos de autenticidade da informação recebida, usar com competência os meios digitais para atingir objetivos pessoais, profissionais ou sociais. Enfatiza-se a necessidade de desenvolver competências de leitura em estudantes universitários. $O$ estudo utilizou métodos de análise conceitual e comparativa, além de métodos psicodiagnósticos e estatísticos. São apresentados os resultados de um estudo empírico realizado em universidades ucranianas. No artigo, apresentamos os aspectos positivos e negativos no uso de publicações impressas e eletrônicas por estudantes modernos e também as suas preferências de uso dessas fontes para resolver problemas educacionais. Determinamos as peculiaridades do desenvolvimento de interesses de leitura dos futuros especialistas e as perspectivas de competição do livro impresso com o digital. Verificamos que os respondentes preferem os e-books, destacando mais vantagens para o uso prático. Foi investigado que para estudar eles escolhem com mais frequência livros impressos, livros didáticos, que os ajudem a focar mais profundamente na informação científica e compreendê-la criticamente (mais de $70 \%$ dos entrevistados). A ênfase é colocada na importância de uma combinação bem-sucedida de publicações digitais e impressas em atividades educacionais (profissionais) nas condições modernas.

Palavras-chave: Cultura de leitura. Digitalização da educação. Estudantes modernos. Livro digital. Livro impresso.

\section{RESUMEN}

El artículo destaca la urgencia del tema de la digitalización de la educación, fundamenta la necesidad de desarrollar la competencia digital de los jóvenes en el contexto del uso de diversos recursos electrónicos, tecnologías, la capacidad de ser críticos en términos de la autenticidad de la información. recibido, utilizar de manera competente los medios digitales para lograr objetivos personales, profesionales o sociales. Se enfatiza la necesidad de desarrollar habilidades lectoras en estudiantes universitarios. El estudio utilizó métodos de análisis conceptual y comparativo, además de métodos psicodiagnósticos y estadísticos. Se presentan los resultados de un estudio empírico realizado en universidades ucranianas. En el artículo, presentamos los aspectos positivos y negativos del uso de publicaciones impresas y electrónicas por parte de los estudiantes modernos y también sus preferencias para usar estas fuentes para resolver problemas educativos. Determinamos las peculiaridades del desarrollo de los intereses lectores de los futuros especialistas y las perspectivas de competencia entre los libros impresos y digitales. Descubrimos que los encuestados prefieren los libros electrónicos, destacando más ventajas para el uso práctico. Se investigó que para estudiar, la mayoría de las veces eligen libros impresos, libros de texto, que les ayudan a enfocarse más profundamente en la información científica y comprenderla críticamente (más del $70 \%$ de los encuestados). Se hace hincapié en la importancia de una combinación exitosa de publicaciones digitales e impresas en actividades educativas (profesionales) en las condiciones modernas.

Palabras clave: Libro digital. Digitalización de la educación. Libro impreso. Estudiantes modernos. Cultura de la lectura.

\section{INTRODUCTION}

In modern conditions of technologicalization of all spheres of public life, digitalization is powerfully carried out (Vuorikari et al., 2016). The era of digital technology allows you to store all photos, posts, texts, videos on electronic media. After all, the transition of the information field to digital technologies, the translation of information into an appropriate format for its further use or dissemination. 
Information resources are one of the most important elements of the resource potential of the university, respectively, information is a key element in educational management (AbelloRomero et al., 2019). At the same time, today we are increasingly talking about digital resources, media to promote the activities of the institution, as well as to increase the efficiency of the educational process for the training of future professionals. Thus, actualizes the problem of developing digital competence of young people in the context of using various electronic resources, technologies, the ability to be critical of the accuracy of information, competently use digital media to achieve personal, professional or social goals.

The expansion of the information environment (Internet, television, books, magazines, etc.) contributes to the fact that information permeates all the activities of a young person and forms an informational way of life. The practical significance of the information environment is that it puts the modern student in front of a choice: print or electronic publications, paper or television media?

An important feature of the information environment is that, for example, for educational purposes or the choice of literature to read in order to meet their own cognitive needs, we have the so-called "scattering" of this information. This means that the same book can be found in print and in various electronic sources. So, along with the printed ones, e-books are becoming more and more widespread today, which are very popular among the younger generation (Roslina et al., 2013). But no matter which book (print or e-book) students choose, it is important that reading is their inner need. It is important to be able to choose the book correctly and consciously, to deeply perceive and understand its content, to critically evaluate the work, and so on.

After all, today the problem of development of reading culture of young people is aggravated, on what results of their professional training at university depend. The concept of "reading culture" lies in the same semantic field with the concepts of "reading competence", "reading literacy", "reading activity", "reading interests", and "reading independence" (Kachak et al., 2021). Reading culture of the individual is a strategically significant factor of spiritual culture, a tool of intellectual development and social activity of a person and a nation in general. Increasing reading culture in schools can have a positive impact on students' learning outcomes (Merga \& Mason, 2019). The issue of development of reading culture, inspiring reading activity, searching for effective methods and ways of motivation of students to read is a subject of scientific and applied research in many world countries (Wojciechowska, 2016; Nyam, 2015).

The task of our study was to substantiate the pros and cons of using printed and electronic publications, to identify the preferences of modern students for their use for educational purposes, to determine the development of readers' interests of future professionals and the prospects of competition with electronic books.

\section{METHODOLOGY}

\section{Research methods}

Methods of conceptual and comparative analysis - used to study the state of the problem in the psychological and pedagogical literature, including electronic sources.

Psychodiagnostic methods - psychological and pedagogical observation, questionnaires of university students to identify their attitudes to e-digital books, their advantages and disadvantages in the learning process.

Statistical methods - for quantitative and qualitative analysis of research results.

\section{Methodology of research}

A questionnaire of own authorship was used in the study as the research tool. The questionnaire was conducted in October 2020 at Vasyl Stefanyk Precarpathian National University and Ivan Franko National University of Lviv (Ukraine). Most of the respondents are future teachers 
(mostly students of the pedagogical faculty). Therefore, the sample was dominated by women (86.3\%). 152 people took part in the survey. Participation in the survey was anonymous.

\section{RESULTS AND DISCUSSION}

It is widely believed that e-books are most popular among young readers. To answer the questions: "Are modern students choosing printed or e-books?", "What are the advantages of a printed book?", "Why is an e-book more convenient to use?", "Which books are more convenient to study?". We conducted a survey in which we were involved future specialists who study at Ukrainian universities.

The sample of our study consisted of persons born in the period 1983-2003 (98\% of respondents).

It was found that in modern students, the worldview is largely formed under the influence of printed books. According to our survey, $77.1 \%$ of respondents prefer printed publications, although they also use electronic ones. At the same time, $18.3 \%$ of respondents choose e-books. It is sad that 7 people out of $153(4.6 \%)$ admitted that they do not like to read books. At the same time, $66 \%$ indicated that they still use e-books more often for everyday learning, and only a third of the total number of respondents use printed books (34\%) (Figure 1).

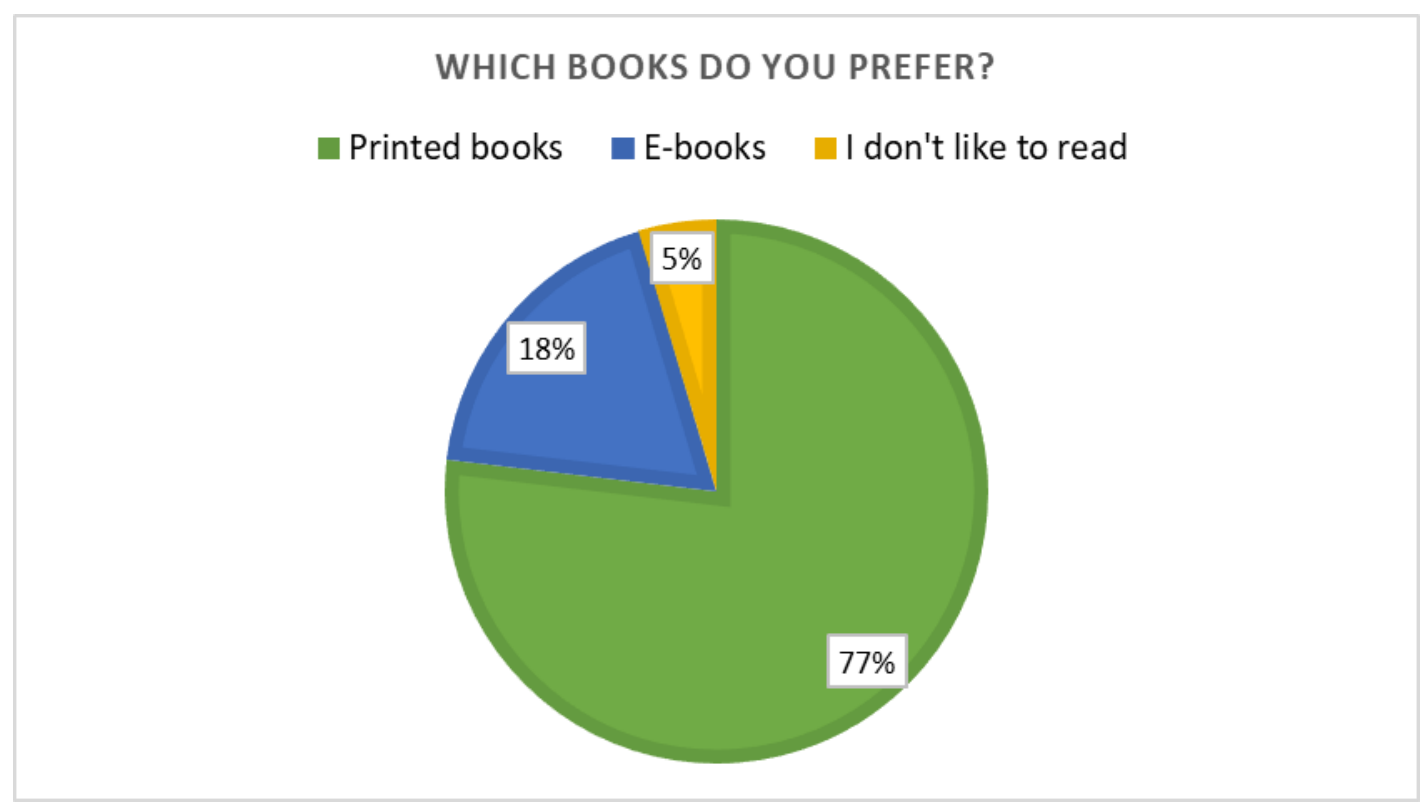

Figure 1. Preferences of modern students for printed and electronic books.

Many researchers believe that students perceive information better when they read printed textbooks. Experts from the University of Maryland have published the results of many years of research on this topic. It turned out that the participants in the experiment read the text on electronic media much faster than in the paper version. The understanding of the content of the reading is approximately the same. But to remember the details, to answer specific questions was much easier for those who read the printed text (Miroshnikova, 2020). Therefore, teachers and students should choose books, reading methods depending on the purpose, including educational: information that needs to be learned in general, it is more useful to present in digital form; and the material to be studied or memorized in detail is in paper form.

Our respondents noted positive points regarding the use of different types of printed and electronic information (Figures 2 and 3 ). As you can see, more than $70 \%$ of respondents said that a printed book is more convenient for the perception, processing and memorization of information, $55.6 \%$ - said that such reading "creates the feeling of a book", fascinates artistic design, etc. At the 
same time, when reading a paper book, the reader is more aware of the events described by the author, as indicated by more than a third of students (34.6\%).

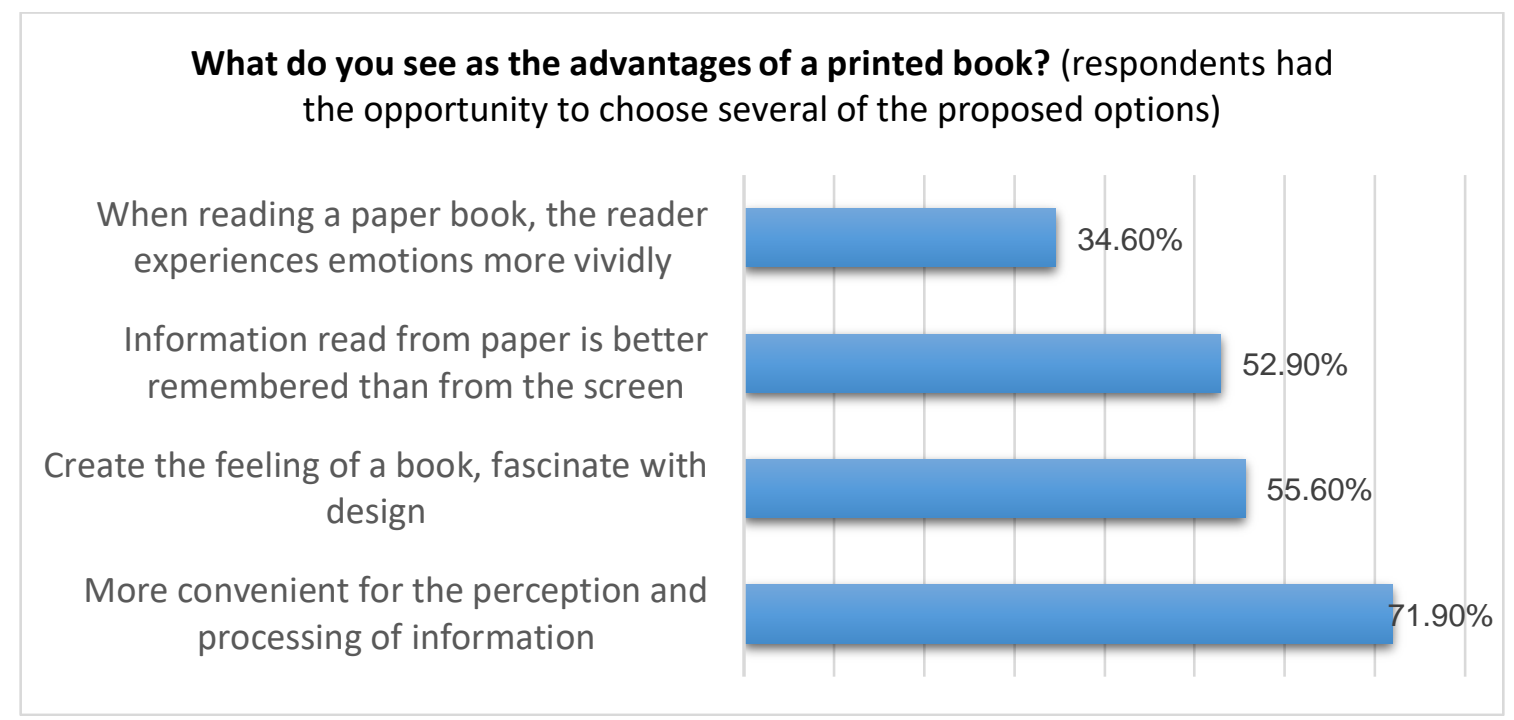

Figure 2. Advantages of a printed book (according to our survey).

Despite the many advantages of printed publications, respondents also pointed out some negative aspects that occur in choosing such a book (Figure 3 ). Thus, 66 students ( $43.1 \%$ of the total number of respondents) noted that printed books are inconvenient because they are difficult to carry, they are often bulky, unlike electronic. More than half of the respondents (55.6\%) admitted that paper books need to be bought or taken in the library, so it takes time, and the electronic edition can be quickly found on the Internet (there are opportunities to access rare editions of world literature). Often books are expensive enough to buy. Therefore, some respondents are justifiably more interested in digital resources.

The "weak" place of printed books modern readers (21.6\%) believe that it may eventually lose its attractive appearance due to some damage, while the e-book can be instantly restored. As we can see, young people today value their time and choose resources to best meet their cognitive needs, to achieve success, and the information space helps in this (Figure 3).

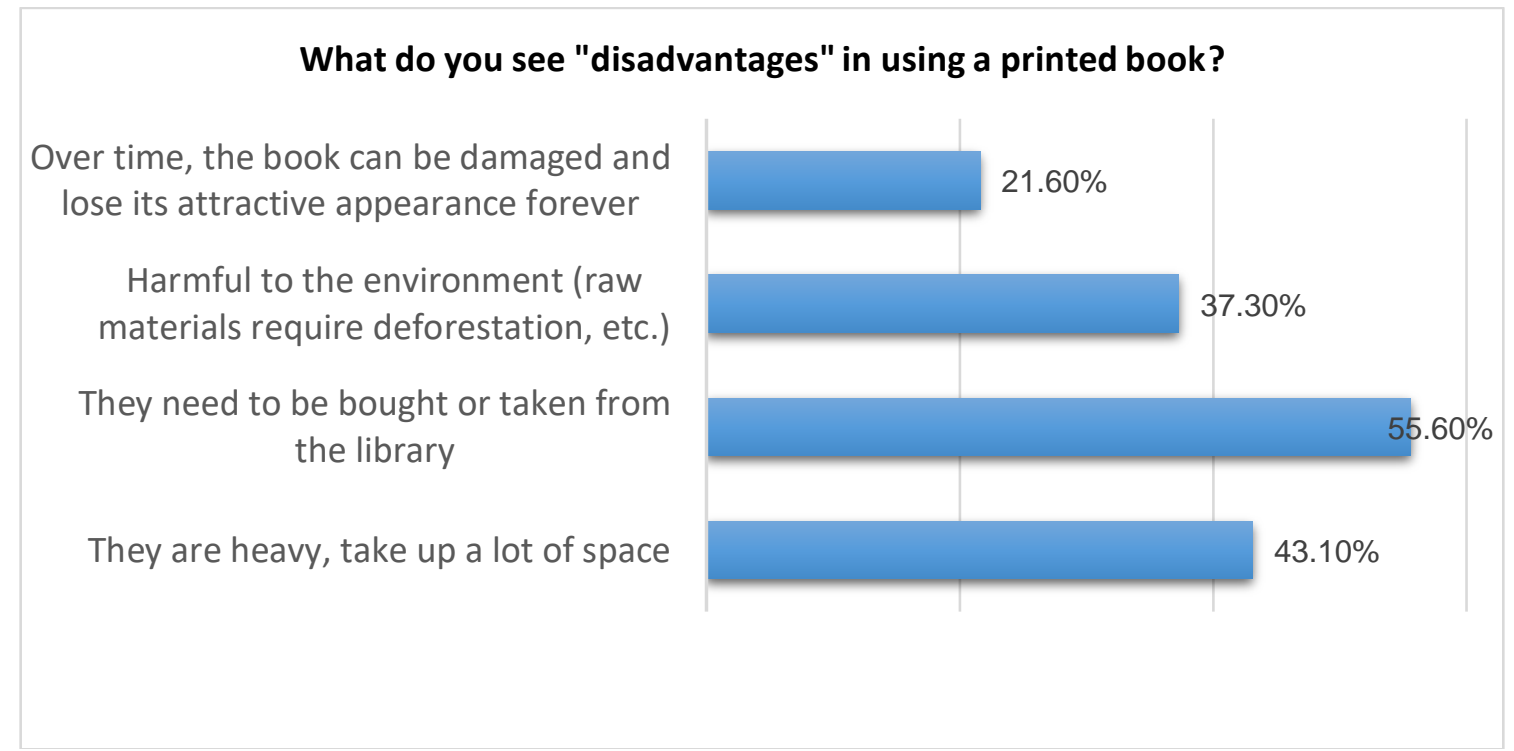

Figure 3. Negative moments in the practical use of the printed book in teaching. 
Modern students belong to the generation that is more concerned about the ecology of the planet, its future. They want to feel comfortable in the world of nature, so it is no coincidence that more than a third of respondents (37.3\%) believe that mass production of paper, book printing is harmful to the environment (raw materials require deforestation), etc. Therefore, they name quite a few advantages in the use of e-books (Figure 4).

Thus, perhaps the most important advantage of the e-book modern young people consider its compactness (this was indicated by 88 respondents, which is $57.5 \%$ ) and ease of use, in particular in transport, on vacation (47.7\%). At the same time, "hundreds of thousands of copies are placed on electronic media, and you can always have them all with you," said 110 respondents (71.9\%).

No lighting is required to use the e-book - it is possible to read at night, adjusting the font and brightness of the screen - said 51 people (33.3\%); mostly free (savings) - 61 people (39.9\%).

\begin{abstract}
"According to a survey conducted last year by Pew Research, half of American adults now own a tablet or e-reader, and that three in 10 read an e-book in 2013. Although printed books remain the most popular means of reading, over the past decade e-books have made a valiant effort at catching up.

Pinpointing the emergence of the first digital book is challenging, however, mostly because people's definition of what constitutes an e-book varies. In the 1970s, Project Gutenberg began publishing electronic text files, and books written in HyperCard followed in the 80s and 90s, pioneered by companies such as Voyager and Eastgate Systems. Later programs and devices for accessing early e-books included the Palm Pilot, Microsoft Reader and Sony Reader. "Microsoft and the Palm experiments around the turn of the century began to really sort of make e-books happen, although not in a substantial, commercial way," says Mike Shatzkin, founder and CEO of the Idea Logical Company, a consultancy group in New York City specialising in publishing's digital transformation" (Nuwer, 2016).
\end{abstract}




\section{What do you see as the benefits of an e-book? \\ (respondents had the opportunity to choose several of the proposed options)}

The appearance of audiobooks helps people with visual impairments, and also allows...

It is possible to access a rare publication in any language, for example opportunities..

If a book is lost, it can be easily recovered by reloading

Do not harm the environment

Mostly free (saving money)

The user spends only a few minutes on the Internet to find and download the required...

It is more comfortable to work with them in various conditions (in transport, on rest)

You do not need lighting to use e-books, you can read at night

Hundreds of thousands of copies are placed on electronic media, and you can always...

More compact than printed books; convenient especially for a student who...

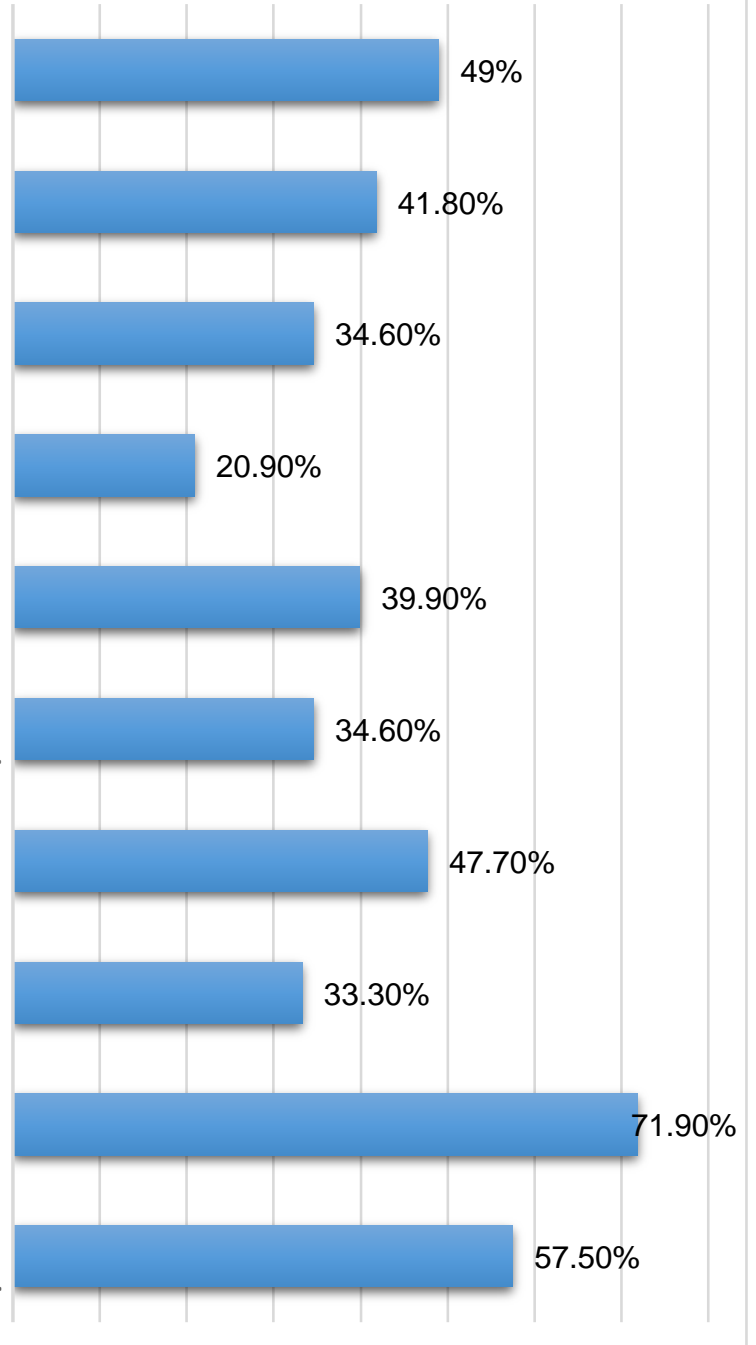

Figure 4. Advantages of the e-book (according to our survey).

It is worth noting that the appearance of audiobooks helps people with visual impairments, as well as allows "reading while traveling", as noted by 75 people (49\%); the user spends only a few minutes on the Internet to search and download the required publication (allow time) - 53 respondents (34.6\%). The same number of respondents noted that the positive point in using an ebook is that in case of loss, it can be easily restored by re-downloading. The ecological aspect is important, because such books do not harm the environment (30 people, ie 20.9\%) (Figure 4).

Despite all the advantages of e-books, students understand the unreliability of electronic media (you can easily lose thousands of books if you lose the gadget) (41.8\%). When working with electronic resources, the eyes get tired faster, vision deteriorates accordingly (79.1\%), spinal curvature occurs more often (posture deteriorates) (19.6\%), etc.

"The experience of a group of Irish university libraries shows that, with the right combination of product and subjects, e-books can thrive among students and faculty, while librarians can create more dynamic, relevant and flexible collections than for print" (Cox, 2004).

Thus, today the public is concerned about the competition between print and electronic publications. And this is natural, because a significant part of citizens believe that these resources will soon cover more than $90 \%$ of the publishing market. 


\section{IS THERE A COMPETITION BETWEEN PRINT AND E-BOOKS TODAY?}

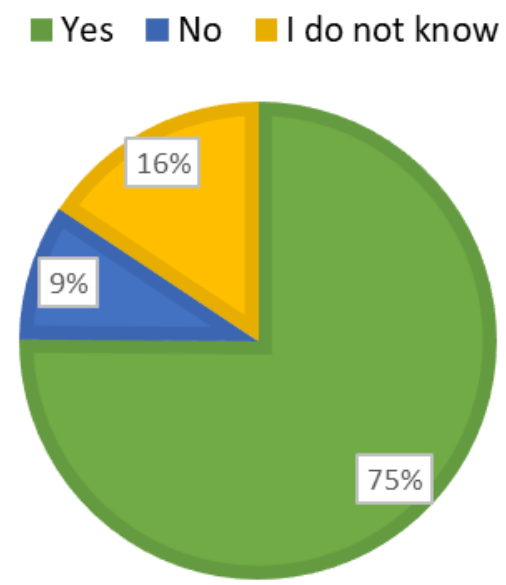

Figure 5. Competition of printed and electronic books (according to students).

"The role of e-books in academic libraries is still not clear, and there is considerable development of standards, technologies and pricing models needed to make the market for e-books viable and sustainable" (Snowhill, 2001). The author convincingly proves that the use of e-books today for reading, including educational purposes in universities, is not yet convenient enough. At the same time there is another problem: "It is not clear that academic libraries can replace print with e-books as a long-term collection goal. There are still concerns about adequate rights to information to support the academic mission of open scholarly communication" (Snowhill, 2001).

So books are only being transformed - digital format is one way to get information. Digital collections in libraries are very popular today. After all, books are a part of our culture, "the depths of the sea" (says the prominent Ukrainian poet and translator Ivan Franko), and the culture of reading is a component of the general culture of the individual. Despite the change of printed books to electronic ones, the dominance of media content, reading still remains a tool of cognition, expanding worldview horizons, self-development of the individual. At the same time, it is worth emphasizing the importance of reading fiction books, literature addressed to young people, the formation of a culture of understanding the text.

University students are a special category who need modern high-quality literary content. Generation $Y$ has its own readers' requests, tastes, and only careful consideration of them by writers or publishers will be able to ensure a lasting interest of the younger generation in books and reading. We are talking about the subject of books, the specifics of plot constructions, the system of current characters, the best narrative practices.

\section{CONCLUSION}

Today, it is difficult to predict which books will be more popular in the future. Stein believes that what is a plateau will now, at some point, return to a steep incline. "We're in a transitional period," he says. "The affordances of screen reading will continuously improve and expand, offering people a reason to switch to screens." The scientist is convinced that the future belongs to the gaming industry, which will also develop books. He proposed project, Social Book, allows members to insert comments directly into digital book texts and is already used by teachers at several high schools and universities to stimulate discussions. "For my grandchildren, the idea that reading is something you do by yourself will seem arcane," he says. "Why would you want to read by yourself if you can have access to the ideas of others you know and trust, or to the insights of people from all over the world?" (Nuwer, 2016). We consider extremely useful skills of digital communication, 
interaction of readers in an online format for discussion of fragments of separate books, to discuss, to exchange opinions. Educational dialogue, accompanied by reading (discussion), is effective for the development of personal and professional values of a young person, his self-improvement (Fomin et al., 2020).

John Cox predicts a bright future with electronic publications, "new products, technologies and opportunities continue to emerge", it is important to use e-books to provide "easier on-screen reading and more flexible, customer-oriented, licensing can be realized" (Cox, 2021).

According to our study, students still prefer e-books, highlighting them more advantages for practical use. However, for educational purposes, they consider more convenient printed books, textbooks that help focus on scientific information in teaching, to comprehend it critically. Therefore, we believe that in modern conditions it is important to successfully combine the activities (learning) of electronic and printed publications. After all, high-quality digital resources can serve as an effective tool for developing the reading interests of young people (Kashora et al., 2016). Thus, both digital and printed books are a source of valuable information. In this context, a significant role belongs to education, the promotion of quality printed and e-books in the modern world to ensure their synergy for effective learning.

Authors' Contributions: Budnyk, O.: conception and design, acquisition of data, analysis and interpretation of data, drafting the article, critical review of important intellectual content; Kachak, T.: conception and design, acquisition of data, analysis and interpretation of data, drafting the article, critical review of important intellectual content; Blyznyuk, T.: conception and design, acquisition of data, analysis and interpretation of data, drafting the article, critical review of important intellectual content; Rostykus, N.: conception and design, acquisition of data, analysis and interpretation of data, drafting the article, critical review of important intellectual content; Boiko, H.: conception and design, acquisition of data, analysis and interpretation of data, drafting the article, critical review of important intellectual content. All authors have read and approved the final version of the manuscript.

Ethics Approval: Not applicable.

Acknowledgments: Not applicable.

\section{REFERENCES}

Abello-Romero, J. B., Mancilla, C., Ganga-Contreras, F. \& Estay-Sepúlveda, J. G. (2019). Determinantes de la divulgación de información en las universidades latinoamericanas para un buen gobierno corporativo. Contaduría y Administración, 64 (4), 1-16. http://dx.doi.org/10.22201/fca.24488410e.2019.2449

Cox, J. (2004). E-Books. Challenges and Opportunities. D-Lib Magazine, 10 (10) October. doi:10.1045/october2004-cox. http://www.dlib.org/dlib/october04/cox/10cox.html

Fomin, K., Budnyk, O., Matsuk, L., Mykhalchuk, O., Kuzenko, O., Sirenko, A. \& Zakharasevych, N. (2020). Dynamics of Future Teachers' Cognitive Readiness Development to Organize Students' Dialogic Learning. Revista Inclusiones, 7 , 276-288.

Kachak, T., Budnyk, O. \& Blyznyuk, T. (2021). Development of reading culture of school children: results of theoretical and empirical research. Revista Inclusiones, 8, 62-76.

Kashora, T., van der Poll, H. M. \& van der Poll, J. A. (2016). E-learning and technologies for open distance learning in Management Accounting. Africa Education Review, 13 (1). https://doi.org/10.1080/18146627.2016.1186863

Merga M. K. \& Mason S. (2019). Building a school reading culture: Teacher librarians' perceptions of enabling and constraining factors. Australian Journal of Education, 63 (2), 14. https://doi.org/ 10.1177 / 0004944119844544

Miroshnikova, A. (2020). Which textbooks are more effective for students - electronic or printed (According to Business Insider, The Conversation, WINK News, The Guardian, BBC, Mental Floss, Telegraph).

https://osvitoria.media/experience/yaki-pidruchnyky-efektyvnishi-dlya-uchniv-elektronni-chy-drukovani/

Nyam, S. S. (2015). The School Library and Promotion of Reading Culture. Delta Library Journal, 9 (1-2), 4-45.

Nuwer, R. (2016). Are paper books really disappearing? BBC Future. https://www.bbc.com/future/article/20160124are-paper-books-really-disappearing 
Roslina, W., Fahmy, S., Fariha, Z., Haslinda, N., Yacob, A., Sukinah, N., Suhana, N. (2013). The Effect of e-Book on Students' Learning Styles A Study in Terengganu, Malaysia. International Conference on Advanced Information and Communication Technology for Education (ICAICTE 2013), 228-231. https://doi.org/10.2991/icaicte.2013.45

Snowhill, L. (2001). E-books and their future in academic libraries: an overview. D-Lib Magazine, 7 (7/8) July/August. doi:10.1045/july2001-snowhill. http://www.dlib.org/dlib/july01/snowhill/07snowhill.html

Vuorikari, R., Punie, Y., Carretero Gomez, S. \& van den Brande, G. (2016). DigComp 2.0: The Digital Competence Framework for Citizens. Publications Office of the European Union. doi 10.2760/38842.

https://ec.europa.eu/jrc/en/digcomp/digital-competence-framework

Wojciechowska, M. (2016). The readership indicators in Poland and programs promoting the reading. Qualitative and Quantitative Methods in Libraries (QQML), 5, 39-48.

Received: 2 July 2021 | Accepted: 6 September 2021 | Published: 30 September 2021

This is an Open Access article distributed under the terms of the Creative Commons Attribution License, which permits unrestricted use, distribution, and reproduction in any medium, provided the original work is properly cited. 